\title{
DOI: 10.19195/1899-5101.10.2(19).7
}

\section{Daphne Skillen (2017). Freedom of Speech in Russia: politics and media from Gorbachev to Putin. New York: Routledge, pp. 363.}

The book under consideration is a comprehensive analysis of the state, role and status of freedom of speech in Russia over the period of thirty-one years, from the beginning of so-called "perestroika" in 1985 to the present day. Taking into account the burden of Russian historical legacy, the author traces the process of emergence, progression and decline of freedom of speech in contemporary Russia and attempts to uncover its logic. Overall, the study aims at an explanation of the historical, psychological and sociological reasons that prevented Russian society from establishing long-lasting freedom of speech and resulted in the "gradual but relentless erosion of the freedoms" (p. 1), gained in the first years after the collapse of the USSR.

The study raises a number of questions, but the central of them, as formulated in the introduction, runs as follows: "Why and how did the dream of democracy and free speech go so wrong, and what can be learned from it?" (p. 1). Indeed, after the three-quarters of a century of Soviet political reality, "glasnost", that was introduced by Gorbachev and was understood as "great autonomy and independence for the media" (p. 122), resembled a dream and caused euphoria in Russian society. In the few years that followed, life in the country transformed dramatically and media professionals for the first time encountered freedom with no restrictions. Yet it did not last long. The media soon "reverted to their traditional role in Russia, as an organ for somebody or something other than truth-telling" (p. 57). In the lifetime of one generation, media once again became "Kremlin mouthpieces" (p. 1) and television was transformed into "instruments of war and hate" (p. 1). So what was it that prevented Russian journalists and society in general from retaining its freedom and how did a nation's dream so quickly turn into a nightmare?

These are not easy questions and obviously a great number of reasons have contributed to the current state of affairs. The study under consideration aims at an objective analysis of all the possible factors and is based on numerous academic and non-academic sources, interviews with prominent Russian politicians, media and law experts and representatives of the media world, as well as on the abundant personal experience of the author, who holds degrees from universities in London, Sydney, and Colorado, and for many years was living and working as a journalist and media critic in Russia.

The study is divided into two parts with the first providing a broad analysis of the freedom of speech in Russia, its historical status and philosophical base, and the second in detail discussing the political history of contemporary Russia and the place of media in it. Thus, the first part begins with an analysis of perceptions of freedom in Russian culture, where this concept can be expressed via two different 
words, namely "svoboda" and "volya" (p. 17). This difference explains why, as illustrated by various surveys, "censorship does not necessarily have negative connotations for Russians" (p. 18). The study compares Western human rights theories which protect the individual at the expense of the powers of the state with Soviet collective thinking, where the state was considered not as "a potential violator of freedoms, but as their guarantor" (p. 21). Additionally, there is the Orthodox Church that challenges freedom and human rights on the grounds that human nature contains sin and thus freedom of choice cannot be regarded as an absolute value (p. 25). The consequences of the growing politically-motivated influence of the Church in modern Russia are illustrated in the book on the example of the trial of Pussy Riot - "a moment when the modern, western, secular mindset clashed with religious obscurantism" and the latter won (p. 27).

The study then proceeds to the analysis of the history of Russian newspapers institutions "imposed from above" (p. 36) by Peter the Great - and censorship that constantly accompanied it from the very beginning. During the Soviet times, "the media were meant to serve the state" (p. 37) and even "glasnost" was invented not to support free speech, but as a means to reform the economy (p. 39). It was only during Yeltins's era when the conditions for freedom of speech "to exist and flourish" (p. 40) in the country were finally created.

The first Russian laws on the the mass media are then discussed in the book, though, as rightfully states the author, "it is not laws alone that encourage free speech, but the political climate" (p. 42). Progressive laws that were created at the beginning of the 1990s were quickly amended when Putin came to power. For instance, the term "extremist" in contemporary Russian laws is "so vaguely defined that it can apply to almost anyone who displeases the authorities" (p. 45). The expansion of "state-owned and state-affiliated media" (p. 48) also contributed to the current state of freedom of speech in Russia under the president, who is not only from the KGB, but is "proud of it" (p. 49).

Among the reasons for the demise of free speech in Russia the study also mentions "a predatory oligarchy concerned with its own interests", "a passive public" (p. 57) and the Soviet legacy - "its illusions, isolationism and deformed thinking" (p. 57). Alas, journalists themselves were a product of that system and often belonged to so-called "Homo Sovieticus" - "a strange and absurdist breed that had mutated after years of fear and lies" (p. 57).

Both fear and lies and their influence on the exercise of human rights are discussed in the book. Both fear and lies have a long history in Russian and Soviet culture, where the state tried to "liberate the world from its chains, while crushing its citizens under poverty and terror" (p.60). In such circumstances, lies were often invented "out of fear and a sense of survival" (p. 90), as a response to the too strict demands imposed on people that were often "impossible to fulfil" (p. 90). Throughout its history, there was and is a lot of fear in Russian society. As a result, claims the author, there is a "bizarre relationship to lies" (p. 90) and "people may accept what 
they see on television without actually believing it" (p. 73). Unfortunately, television in Russia is a dangerous instrument, "opium of the people" (p. 73). It is watched by 90 per cent of the population on top of "political apathy, conformism and subservience to the ruling class" (p. 73).

The study attempts to uncover the rationale behind these characteristics of Russian society and examines "feelings of insecurity and competitiveness" (p. 95) felt by the country where a historical serfdom lasted longer than in any other part of Europe. Time passes, but "the same unresolved and unchanged problems continue to suffocate Russia" (p. 99) and the $20^{\text {th }}$ century has only contributed to it. Historical revisionism has never been conducted in Russia, as all the political leaders after Stalin feared that a trial into the crimes of communists "would result in civil war" (p. 102). History of killings and repressions against its own people is still an overly sensitive issue and to address it people need "support of government, the judiciary, education and media" (p. 102). Without this long-needed operation on the nation's conscience, there is "no healing process and no catharsis" (p. 102).

Overall, the first part of the study discusses the historical reasons behind Russian "dysfunctional society" (p. 49) and provides its explanation. The Russian audience was not gullible, but cautious and inured to "distortions of reality after a legacy of seventy years of lies, unverifiable information and isolation from the outside world" (p. 49), and it was not the foundation that was necessary for establishing long-lasting freedom of speech. People easily succumbed to demagogy (p. 106) and passively lost the chance for a better future.

The detailed process of how it happened is described in the second part of the book. It is devised into four chapters and chronologically examines freedom of speech under Gorbachev, during the coup of 1991, in the Yeltsin era, and under Putin. "Perestroika" and "glasnost" are examined in the book as the major achievements of Gorbachev. Yet in 1986 the Chernobyl disaster - the world's worst nuclear disaster - "was reported in five short sentences" (p. 118). But in the next few years the unprecedented rise of freedom of speech happened. Eventually, "glasnost" became the policy that "largely contributed" to the fall of Gorbachev himself and the Soviet Union (p. 39). "Liberalisation turned into democratisation" (p. 149) and the society proved it was capable of defending its new freedom during the three-day coup in August 1991. The coup is then described in the book, as well as its significance for freedom and democracy in the country. Yet, states the author, twenty years later perceptions of the coup have dramatically changed, showing that "over the last two decades people have lost the confidence they had in themselves as political actors" (p. 164).

The Yeltsin era is discussed in great detail in the book, as it was the time when the country "enjoyed a degree of free speech unprecedented in scope and duration" (p. 187). The author claims that Yeltsin "freed society from fear" (p. 187) and protected media freedom. Yet, "the right to free speech needs people prepared to speak freely" (p. 192) and Russian media appeared to be not prepared. Instead, free and 
honest journalism quickly became "a hostage to politics and money" (p. 212). The introduction of advertising and sponsorship and following enormous amounts of money corrupted media professionals and in the late 1990s bribery and corruption were flourishing almost everywhere in the main national media (p. 216).

Finally, the last chapter of the book examines the fate of freedom of speech and the destruction of media pluralism in Russia under the Putin regime. Once in power, "Putin declared that journalism was like spying" (p. 279) and began the Kremlin's war with the media, states the author. The rise of suspicion and paranoia in modern Russia is explored in the study together with the fate of the once-independent NTV channel and the emergence of the new state-controlled media. The most horrific events in modern Russian history, such as the Kursk disaster, Nord-Ost siege, Beslan, proved the "Kremlin's obsession with media and with controlling its image" (p. 301). Moral outrage did not happen. The society, as well as media professionals, largely accepted "Putin's increasingly authoritarian regime" (p. 304). The relationship between the state and media returned to its feudal prototype.

To conclude, the book examines the role and state of freedom of speech in Russia over the last thirty-one years and reflects the underlined processes and factors that contributed to its current condition. The study comprises hundreds of stories and examples from Russian political history that overall create a comprehensive picture of tragedy of Russians, who may be considered hostages of "superpower status at the expense of ordinary people" (p. 61). As such, the study can be highly recommended to media professionals, academics and students, engaged with the issues of media and freedom of speech, as well as to everyone interested in the history of contemporary Russia and in understanding it. 